\title{
Copepod carcasses in the ocean. I. Over seamounts
}

\author{
Loren Haury ${ }^{1}$, Connie Fey ${ }^{1}$, Gideon Gal ${ }^{2}$, Alistair Hobday ${ }^{1}$, Amatzia Genin ${ }^{2}$ \\ ${ }^{1}$ Marine Life Research Group, Scripps Institution of Oceanography, La Jolla, California 92093-0218, USA \\ ${ }^{2}$ The Hebrew University, H. Steinitz Marine Biology Laboratory, PO Box 469, Eilat 88103, Israel
}

\begin{abstract}
Higher abundances of copepods with external damage or in various states of internal decay have been found in shallow waters over banks, ridges and seamounts than in the surrounding waters. The increase occurred in 3 of 5 sets of multiple opening-closing net tows taken at Fieberling Guyot, Northeast Bank and Sixtymile Bank, west of San Diego, California, USA. Large numbers of copepod carcasses were also found above the summit of Jasper Seamount. The carcasses are attributed to higher levels of predation over shallow topographic features due to resident organisms that ascend above the summits at night to feed. At Fieberling Guyot (summit depth of about $500 \mathrm{~m}$ ), this migration was at least $400 \mathrm{~m}$ above the summit. Carcasses identical to those collected in the net tows were produced in the laboratory by euphausiids feeding on copepods
\end{abstract}

KEY WORDS: Copepod $\cdot$ Carcass $\cdot$ Seamount $\cdot$ Predation

\section{INTRODUCTION}

Copepods with external damage or various states of internal decay are often found in zooplankton samples (e.g. Farran 1926, Wheeler 1967, Weikert 1977, Terazaki \& Wada 1988, Beyer 1992). Their condition ranges from those with slightly damaged carapaces or a few missing appendages to completely empty exoskeletons or fragments of exoskeletons (Ponomareva 1954, Ohman 1984, Geptner et al. 1990, Beyer 1992). These copepods result from (1) natural mortality unrelated to predation (e.g. starvation; after reproduction), (2) injury or incomplete consumption due to predation, (3) egestion of partial or complete copepod exoskeletons by predators, (4) release of partially consumed prey during net capture, (5) net damage or cod end feeding during collection, and (6) preservation and sample handling. Both predation and decay can result in partially empty to empty exoskeletons (Harding 1973, Beyer 1992).

Some studies report the frequency of occurrence of dead copepods as a function of depth in the water column (e.g. Farran 1926, Sameoto 1986, Roe 1988) or in relation to height above the bottom and bottom depth (Wishner 1980a). Other reports note their relationship to large patches of zooplankton (Wishner et al. 1988), to hydrographic features such as upwelling and downwelling (Weikert 1977, 1984), intrusions (Weikert
1975 ) and current systems (Oyashio: Terazaki \& Wada 1988; Gulf Stream edge: C. Davis pers. comm.). We have found high abundances of dead copepods (Fig. 1), some in relatively shallow waters, over abrupt topographic features (banks, ridges and seamounts) as deep as $500 \mathrm{~m}$. Laboratory observations on feeding by living animals show that euphausiid and other micronekton predation can produce copepod remains identical to those found in net tows, thus supporting predation as a causal mechanism.

\section{METHODS}

Samples were collected at Jasper Seamount $\left(30^{\circ} 22^{\prime} \mathrm{N}\right.$, $\left.122^{\circ} 43^{\prime} \mathrm{W}\right)$, Fieberling Guyot $\left(32^{\circ} 25^{\prime} \mathrm{N}, 127^{\circ} 47^{\prime} \mathrm{W}\right)$, Northeast Bank $\left(32^{\circ} 20^{\prime} \mathrm{N}, 119^{\circ} 37^{\prime} \mathrm{W}\right)$ and Sixtymile Bank $\left(32^{\circ} 05^{\prime} \mathrm{N}, 118^{\circ} 15^{\prime} \mathrm{W}\right)$ (Fig. 2). The summit depths (surrounding depths in parentheses) are $527 \mathrm{~m}$ $(4200 \mathrm{~m}), 428 \mathrm{~m}(4200 \mathrm{~m}), 360 \mathrm{~m}(1400 \mathrm{~m})$ and $100 \mathrm{~m}$ $(1500 \mathrm{~m})$, respectively.

Jasper Seamount was sampled in 1984 with the Deep-Tow triplicate opening/closing net $(183 \mu \mathrm{m}$ mesh) (Wishner 1980b). Two tows of 3 samples each (sample length about $1 \mathrm{~h}$ ) were made over the seamount; each tow was a continuous transect from about $1100 \mathrm{~m}$ depth on the flanks to $600 \mathrm{~m}$ near one of the 


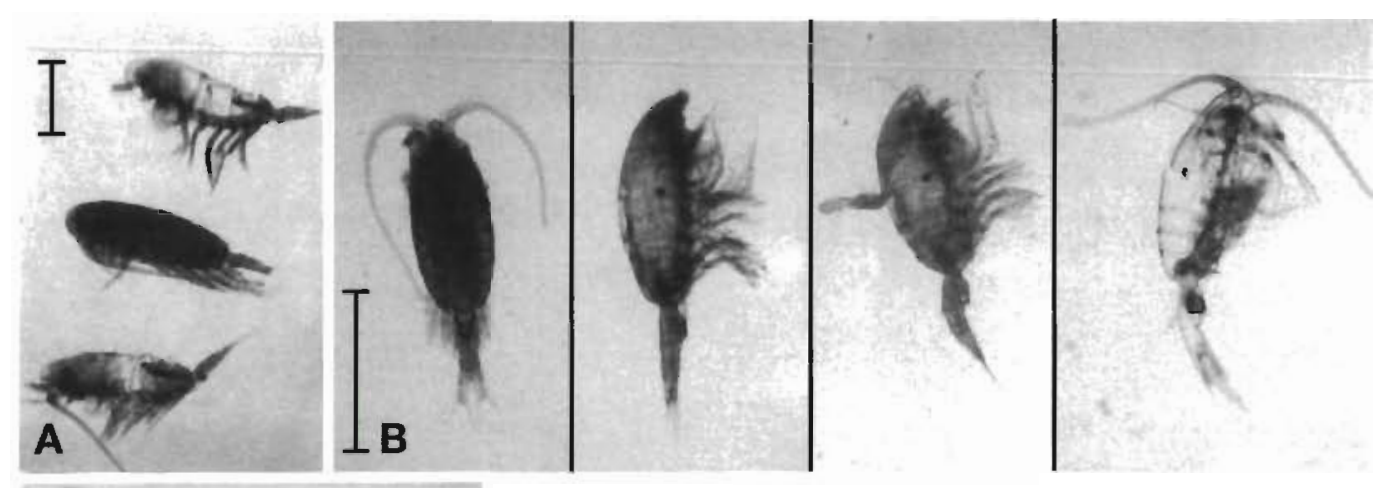

Fig. 1. Examples of copepods collected alive and as carcasses at Sixtymile Bank; they are representative of all seamounts sampled (see Fig. 2 for locations). (A) Calanus pacificus females; the copepods on each side of the undamaged specimen have had portions of their cephalosome removed through wounds in the dorsum. (B) Pleuromamma borealis females; sequence of damage from uninjured specimen to empty husk (with some tissue remaining). (C) Metridia pacifica females; examples of undamaged and eviscerated individuals; (D) 4 partially consumed specimens. Compare all the above with those in Figs. 3 to 22 in Beyer (1992). Scale bars: $1 \mathrm{~mm}$

multiple summits. Distance above the bottom was $77 \mathrm{~m}$ $( \pm 46 \mathrm{~m})$ and $183 \mathrm{~m}( \pm 78 \mathrm{~m})$ for the 2 tows [see Table 1 and Genin (1987) for details].

The other seamounts were sampled in 1989 with a 9-net and in 1990-1991 with a 20-net (333 $\mu \mathrm{m}$ mesh, $1 \mathrm{~m}^{2}$ ) MOCNESS (Wiebe et al. 1985). Tows were taken over and in the deep water areas on 2 sides of the seamounts (average time of tows $160 \mathrm{~min}$, SD $48 \mathrm{~min}$, $n=34$ ). Subsets of samples from the total number collected by each MOCNESS tow were selected for analysis. Table 1 presents other details of the sampling

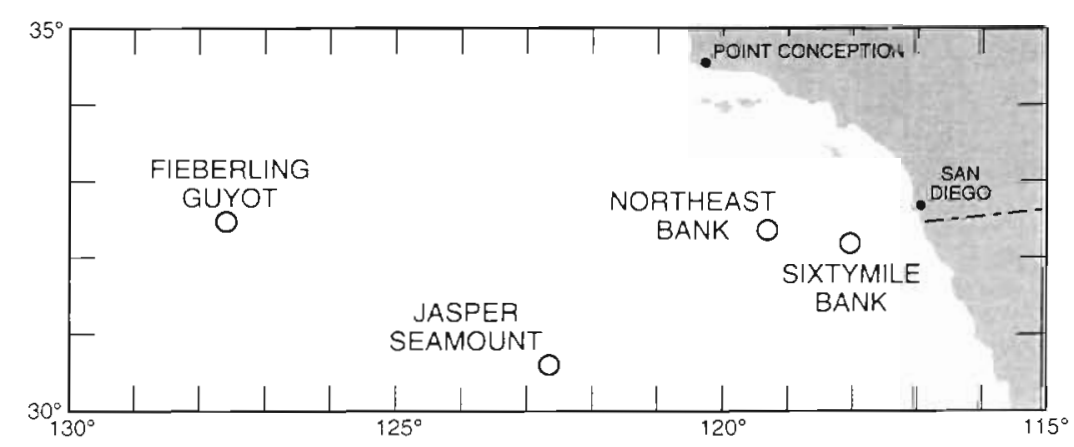

Fig. 2. Locations of the 4 seamounts sampled protocol and samples obtained. Overall our analysis is based on 147 samples obtained from 4 oceanic sites using 2 net systems.

The discrimination between damaged and undamaged copepods is usually not a problem; the basis for this judgment has been described (Wheeler 1967 , Genin 1987, Geptner et al. 1990, Beyer 1992, Geynrikh 1992). A difficulty arises in distinguishing categories within the range of damage from slight, with no missing tissue, to nearly empty exoskeletons. Copepods, presumably captured dead, were classified as 'marginal' (damaged carapaces and/ or easily visible decayed internal structure) and 'husks' (little or no tissue in the exoskeleton). Because the division point is subjective, however, for statistical analyses all degrees of damage and decay were lumped into 1 group called carcasses (Wheeler 1967, Weikert 1977 , Terazaki \& Wada 1988).

Empty exoskeletons resulting from complete decay or digestion were not distinguished from molt exuviae. 
Table 1. Number of samples analyzed from the regions over and away from the summits of the 4 seamounts. Also listed are the cruise dates, sampling depths, type, and number of tows. All samples were collected at night, except those at Jasper Seamount were taken during the day

\begin{tabular}{|c|c|c|c|c|c|c|c|}
\hline \multirow[t]{2}{*}{ Location } & \multirow[t]{2}{*}{ Date } & \multirow[t]{2}{*}{ Depth $(m)$} & \multirow[t]{2}{*}{ Type of tow } & \multicolumn{2}{|c|}{ No. of tows } & \multicolumn{2}{|c|}{ No. of samples } \\
\hline & & & & Over & Away & Over & Away \\
\hline Jasper Seamount & Sep 1984 & $550-1080$ & Oblique & 2 & - & 6 & - \\
\hline \multirow[t]{3}{*}{ Fieberling Guyot } & Sep 1989 & $0-600$ & Oblique & 2 & 2 & 14 & 10 \\
\hline & Sep 1990 & $95-105$ & Horizontal & 2 & 6 & 8 & 19 \\
\hline & Sep 1991 & $60-85$ & Yoyo & 4 & 5 & 9 & 17 \\
\hline Northeast Bank & Sep 1990 & $55-65$ & Horizontal & 3 & 5 & 7 & 17 \\
\hline Sixtymile Bank & Sep 1991 & $30-55$ & Yoyo & 1 & 2 & 20 & 20 \\
\hline
\end{tabular}

Beyer (1992) showed that euphausiid predation left muscle tissue remains in appendages and assumed that completely empty exoskeletons were exuviae. Decay over time, however, depending on temperature (Wheeler 1967. Harding 1973), can produce completely empty exoskeletons. Some predators also ingest whole copepods and excrete empty but structurally perfect exoskeletons (Genin et al. 1995, this volume).

All comparisons of carcass abundance over and away from the topographic features were made using the nonparametric independent sample proportions test (Tate \& Clelland 1957).

The damage to copepods collected over the seamounts was consistent with invertebrate predation which produces whole body carcasses (Yen 1983, Ohman 1984, Beyer 1992). Laboratory observations on the feeding and defecation of potential planktonic predators were used to demonstrate the production of carcasses. An oblique bongo net tow to $100 \mathrm{~m}$ collected live zooplankton over Sixtymile Bank (Fig. 2) at 02:00 h local time, 11 May 1994. Ten adult Nematoscelis difficilis (euphausiids) were separated into a $4 \mathrm{l}$ container of filtered seawater with 32 Calanus pacificus (copepods: stage CV and adult) collected in the same tow. Eleven larvae of the rockfish family Scorpanaeidae ( $<10 \mathrm{~mm}$ length) were placed in filtered seawater in a similar container. After $6 \mathrm{~h}$ in the lighted ship's laboratory, the water from each container was filtered and examined for copepod carcasses, either free or contained in fecal pellets.

\section{RESULTS}

Jasper Seamount. Samples were collected at a relatively constant altitude above the seamount as the net was towed up the seamount slope; the percent occurrence of carcasses increased as the summit was approached in both tows (Fig. 3). While no statistical significance can be assigned to the differences or trend, the increase could be due to more predation/ predators/prey at shallower depths and/or to en- hanced resuspension of carcasses by the stronger currents at the summit.

Fieberling Guyot. The oblique tow series taken over and away from Fieberling Guyot in September 1989 illustrate the vertical distribution of carcass proportions (Fig. 4). There was a clear increase with depth to $500 \mathrm{~m}$ (the seamount summit); below the summit depth, the percentage declined. At all depths over the seamount, the percentage of carcasses was higher; this difference was significant at 3 of the 4 depths.

The September 1990 horizontal tows over and away from Fieberling showed significantly more carcasses over the guyot (Fig. 5A). In contrast, there was no significant difference between localities in September 1991 (Fig. 5B). This difference in results between years may be due to natural variability in the processes creating or possibly retaining the carcasses, or to sampling differences between years. The 1991 net tows were shallower than in 1990 (Table 1); since shallower depths have lower percentages of carcasses (1989 results, Fig. 4), this may have prevented detection of significant differences in the relative abundance of carcasses.

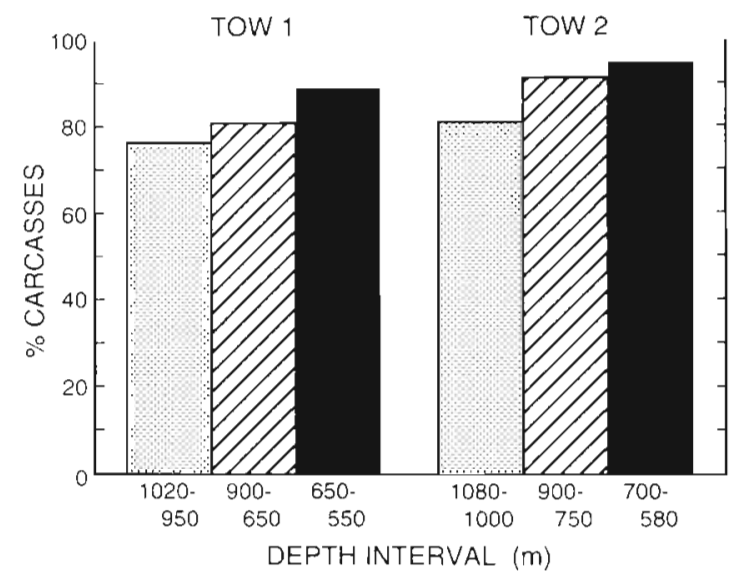

Fig. 3. Jasper Seamount. Percentage of total copepods captured that were carcasses as a function of depth interval sampled by the 2 tows up the flank of the seamount; tow details in Table 1. 


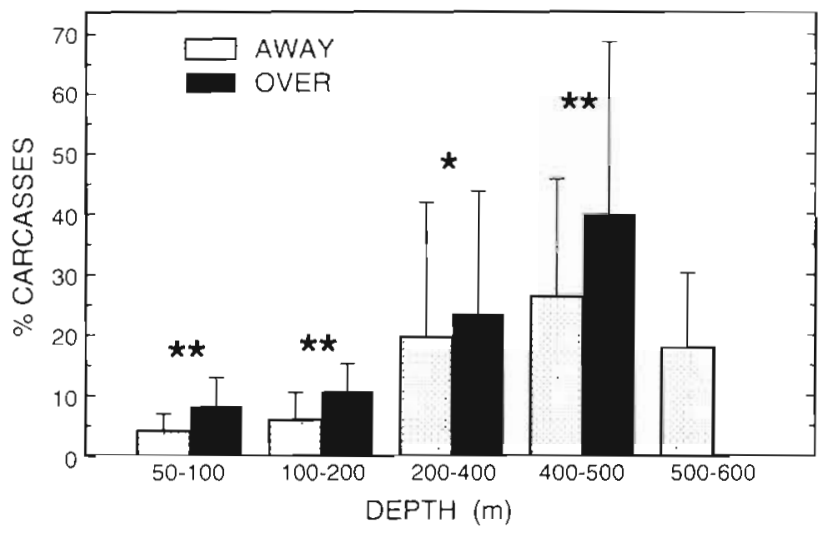

Fig. 4. Fieberling Guyot. Distribution of percentage of copepod carcasses as a function of depth and position relative to seamount. Samples collected during September 1989; details in Table 1 Values are means + SD. Significant differences: " $p<0.1, \cdots p<0.05$

Northeast Bank. There was no significant difference in the relative abundance of carcasses over and away from Northeast Bank in September 1990 (Fig. 5C); this may be due to the depth of the bank $(360 \mathrm{~m})$ relative to the migratory pattern of animals (both zooplankton and resident predators) in the shallow, relatively eutrophic waters, or to natural variability in the phenomenon. Or, as at Fieberling, the sampling depth may have been too shallow for such a deep topographic feature.

Sixtymile Bank. Like the Fieberling 1989 and 1990 results, the tows at Sixtymile Bank (Fig. 5D) showed a significant increase of carcasses over, as compared to away from, the bank.

Laboratory observations. At the end of the $6 \mathrm{~h}$ feeding period in the laboratory with 32 Calanus pacificus as prey for 10 euphausiids (Nematoscelis difficilis), 3 carcasses and 29 living copepods were recovered. The carcasses produced were identical to those collected over the seamount (Fig. 1); each had the diagnostic break in the dorsal prosome with a large fraction of the internal tissue removed.

No copepod carcasses were found in fecal material produced by the Scorpanaeidae larvae.

\section{DISCUSSION}

An analytical problem affecting the evaluation of our results is the difficulty in attributing the damage observed to natural causes or to that occurring in the net during collection (net damage, cod end feeding, regurgitation during capture) or afterwards due to sample processing and preservation. The literature is contradictory in how this problem is treated for

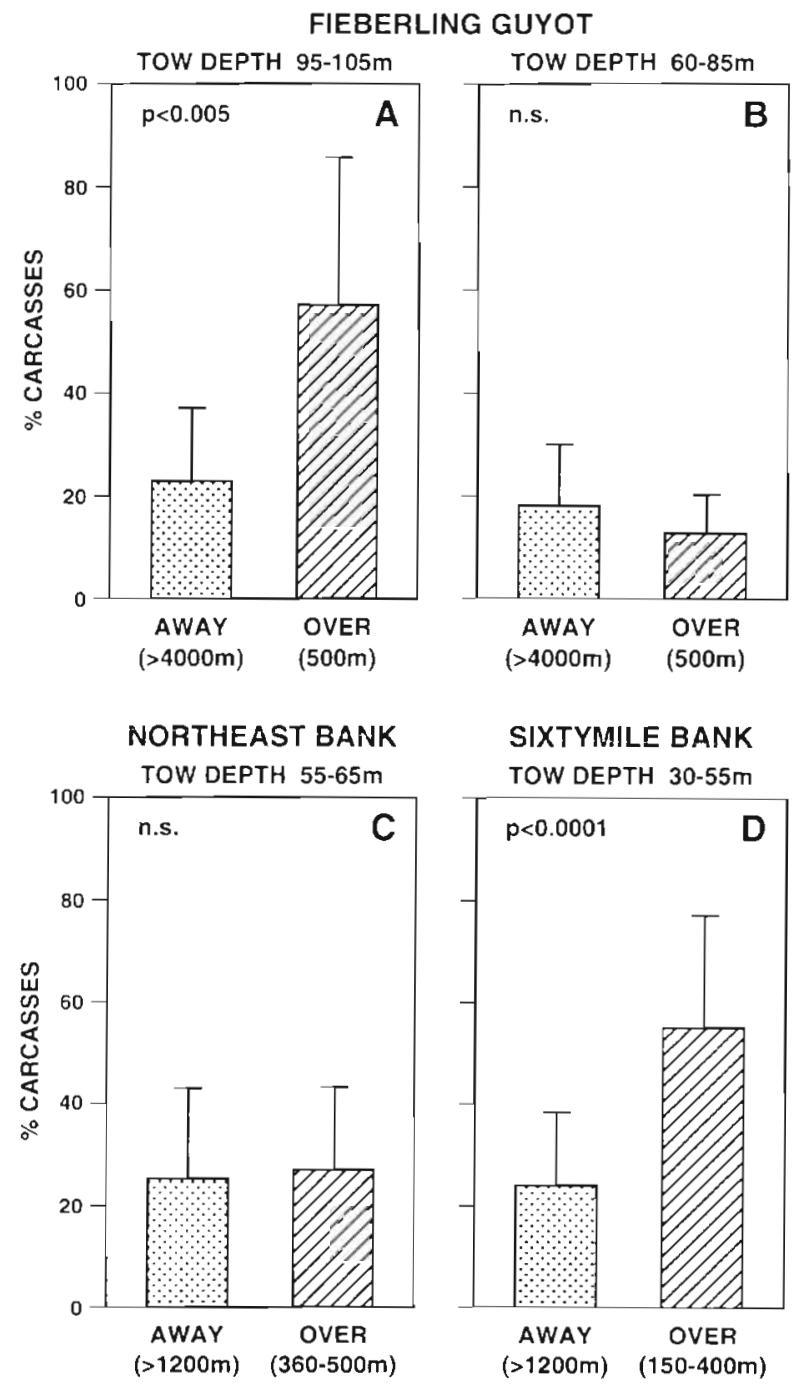

Fig. 5. Relative abundance of copepod carcasses as a function of position with respect to 3 seamounts. (A) Fieberling Guyot, September 1990 and (B) September 1991; (C) Northeast Bank, September 1990; (D) Sixtymile Bank, September 1991 Values are means + SD

example, Wishner (1980a) and Wiebe et al. (1988) assumed that all copepods in poor condition were due to net damage and counted them as living. Other authors, however (e.g. Weikert 1977, Geynrikh 1992), attempted to distinguish living from dead copepods. Our samples showed some evidence of net damage, i.e. the number of copepods in poor condition in a few tows increased with increasing length of tow. We believe, however, that most carcasses resulted from natural processes, not net damage, because (1) the perfect condition of many carcasses precludes net damage; (2) damage to many copepods (Fig 1) closely resembled that due to predation by euphausiids (Ponomareva 1954, Ohman 1984, Beyer 1992, our feeding 
observations reported here), copepods (Yen 1983), and fish (Strickler pers. comm.) and not the crushing and loss of appendages typical of net damage; and (3) time from capture to preservation was insufficient to explain the extent of decay observed (Wheeler 1967 , Harding 1973). This latter fact also suggests feeding in the cod end was not an important source of carcasses. In addition, Genin et al. (1995) gently sampled copepods around coral reefs with diver-controlled nets and rapid, careful preservation a few minutes after collection. The carcasses in these samples, obviously not a result of net damage or cod end feeding, were similar to those collected in this seamount study. Also, since our sampling system and deployment technique were similar at both the over and away sites, if our results were due to cod end feeding alone there should have been no significant difference between locations.

The Jasper Seamount samples also are evidence against net damage, length of time in the cod ends or cod end feeding as a significant factor in producing the carcasses. The samples from the shallowest depths (sampled last) of both tows had the highest percentage of carcasses (Fig. 3). Similarly, the depth distribution of carcasses at Fieberling Guyot (Fig. 4) shows that the percentage of carcasses in the deepest samples (sampled first, thus in the cod ends longest) decreased.

The high abundance of copepod carcasses over abrupt topographic features in 4 of 5 data sets from 4 geographic locations supports the hypothesis that this phenomenon may occur frequently in regions with such topography. We attribute much of the phenomenon to the increased level of predation over topographic features due to resident organisms that ascend above the summits to feed in the water column. This predation, and the interactions of vertically migrating zooplankton with the bottom (i.e. either their physical displacement by the summit or feeding on them by sessile organisms), has been found to reduce the numbers of living zooplankton over abrupt topography (Nellen 1973, Weigmann 1974, Perissinotto \& McQuaid 1992, Genin et al. 1994).

We believe the copepod carcasses result from predation for the following reasons: (1) the damage to many of the carapaces resembles that caused by euphausiids in our shipboard studies and in the studies of others (Ponomareva 1954, Ohman 1984, Beyer 1992); (2) some vertebrates (fish: Chitty 1981, Hobson 1991, Redden \& Daborn 1991, Conway et al. 1993, Flinkman et al. 1994 , Genin et al. 1995) and invertebrates (crinoids, corals: Sebens \& Koehl 1984, Lewis 1992, Genin et al. 1995; gelatinous zooplankton: R. Harbison \& J. Purcell pers. comm.) ingest whole copepods and egest fragmentary to complete exoskeletons identical to those found in our seamount samples. Strickler (pers. comm.) has high speed video observations of small trigger fish attacking large copepods. They completely empty the prosome through a wound in the dorsum, leaving carcasses similar to those shown in Fig. 1.

We presume that the predation on copepods occurs during the night, the usual time when migrators are in shallower water and when most seamount organisms leave the bottom to prey in the water column (Genin et al. 1988, Wilson \& Boehlert 1990, 1993). Additional support for predation by micronekton comes from an analysis of the contents of food baskets of penaeid shrimp (Benthysicymus sp.) collected in May 1994. Zooplankton remains of many different taxa were removed from the baskets after the shrimp were left alive for several hours in a bucket holding the mixed contents of the net cod end. These remains contained copepod carcasses with varying degrees of damage that were similar to those collected over the seamounts.

The surprising feature of our data is the presence of increased numbers of carcasses high above such a deep seamount as Fieberling. These data suggest that predators residing on seamounts are capable of ascending at least $400 \mathrm{~m}$ above the summit $(100 \mathrm{~m}$ below the surface) to feed. What are these predators? There is considerable literature on the existence of seamount-and slope-associated mesopelagic fish and micronekton (Ehrich 1977, Gjosaeter \& Kawaguchi 1980, Parin \& Prut'ko 1985, Parin 1986, Reid et al. 1991). Lonsdale (pers. comm.) has reported swarms of unidentified 'orange shrimp' above the summit rim of Fieberling Guyot.

There is far less literature, however, on the timing and extent of the vertical migrations of these seamount residents. Rockfishes above Nidever Bank off southern California forage tens of meters above the summit in the early morning (Genin et al. 1988). Boehlert \& Genin (1987) showed acoustic backscatterers, presumably the fish Maurolicus muelleri (known to feed on copepods of the genus Pleuromamma; Boehlert pers. comm.), migrating upward from the flanks of South Hancock Seamount ( 250 to $300 \mathrm{~m}$ ) to depths of 40 to $60 \mathrm{~m}$. At the same seamount, Wilson \& Boehlert (1990, 1993) found nocturnal migrations of about $100 \mathrm{~m}$ by $M$. muelleri, Pseudopentaceros wheeleri and the mysid Gnathophausia longispina. The seamount-associated cephalopod Iridoteuthis iris has been captured $200 \mathrm{~m}$ above Kammu Seamount (summit depth $350 \mathrm{~m}$ ) northwest of Hawaii (Harman \& Seki 1990). In a roughly analogous situation that lends support to extensive diel foraging migrations away from home territories by small fish, Gosline (1965), Hobson (1972) and Hobson \& Chess (1973) reported that reef fish undertook evening horizontal migrations of up to $2 \mathrm{~km}$ from reefs to feed in open, deep water at night.

The extensive vertical migrations implied by our data heighten the mystery of how migrating seamount 
resident predators return to the summits after their excursion to near the surface. Both good navigation ability and swimming ability are necessary, or there must be some consistent physical return mechanism like recirculation in wake eddies or Taylor columns/ caps. The report of Wilson \& Firing (1992) on apparent homing ability of micronekton sound scatterers at ranges of several kilometers from Southeast Hancock Seamount discusses some of the possible mechanisms.

We believe the copepod carcasses found over shallow abrupt topography are a result of one of the processes creating zooplankton gaps, or holes, over seamounts (Genin et al. 1994). This feature is highly predictable in space and time, in that the gap appears at a geographically fixed location (i.e. over the topographic feature) every night. Seamounts would therefore be ideal sites for studying water column predation. Carcasses, the residue of this predation, may be a way of quantifying predation rates and of gaining a better quantitative understanding of the transfer of energy to seamount populations.

Acknowledgements. Supported by Office of Naval Research contracts N00014-82-K-0147, N00014-89-J-1539, N00014-92J-1675, NSF grant OCE85-10057, and United States-Israel Binational Science Foundation (Jerusalem) grant no. 88-351 We thank Dr L. Zelickman, I. Ayalon, J. Bowman, W. Newland, F. Escritor and others who helped collect and process the samples and data. Dr K. Wishner provided the Deep-Tow zooplankton net system for the Jasper study. Drs J. Purcell, L. Madin, and R. Harbison shared their knowledge of the feeding, digestive, and excretory habits of gelatinous zooplankton

\section{LITERATURE CITED}

Beyer F (1992) Meganyctiphanes norvegica (M. Sars) (Euphausiacea) a voracious predator on Calanus, other copepods, and ctenophores, in Oslofiorden, southern Norway. Sarsia 77:189-206

Boehlert GW, Genin A (1987) A review of the effects of seamounts on biological processes. In: Keating BH, Fryer P, Batiza R, Boehlert GW (eds) Seamounts, islands and atolls. Geophysical Monograph 43, American Geophysical Union, Washington DC, p 319-334

Chitty $N$ (1981) Behavioral observations of feeding larvae of bay anchovy, Anchoa mitchilli, and bigeye anchovy, Anchoa lamproteania. Rapp P-v Réun Cons int Explor Mer 178:320-321

Conway DVP, Tranter PRG, Coombs SH (1993) Digestion of natural food by the larval and post-larval turbot Scophthalmus maximus. Mar Ecol Prog Ser 100:221-231

Ehrich S (1977) Die Fischfauna der Großen Meteorbank. 'Meteor' Forsch-Ergebn 25:1-23

Farran GP (1926) Biscayan plankton collected during a cruise of H.M.S. 'Research', 1900. Part XIV. The Copepoda. $J$ Linn Soc (Zool) 36:219-310

Flinkman J, Vuorinen I, Christiansen M (1994) Calanold copepod eggs survive passage through fish digestive tracts. ICES J mar Sci 51:127-129
Genin A (1987) Effects of seamount topography and currents on biological processes. PhD thesis, University of California, San Diego

Genin A, Gal G, Haury L (1995) Copepod carcasses in the ocean. II. Near coral reefs. Mar Ecol Prog Ser 123:65-71

Genin A, Greene C, Haury L, Wiebe P, Gal G, Kaartvedt S, Meir E, Fey C, Dawson J (1994) Zooplankton patch dynamics: daily gap formation over abrupt topography. Deep Sea Res 41:941-951

Genin A, Haury L, Greenblatt P (1988) Interactions of migrating zooplankton with shallow topography: predation by rockfishes and intensification of patchiness. Deep Sea Res 35:151-175

Geptner MV, Zaikin AN, Rudyakov YuA (1990) Dead copepods in plankton: facts and hypotheses. Oceanology 30 : 99-102

Geynrikh AK (1992) Copepods in the bottom layer of Walters Seamount (Southwestern Indian Ocean). Oceanology 32: $84-88$

Gjosaeter J, Kawaguchi K (1980) A review of the world resources of mesopelagic fish. FAO Fish tech Pap 193

Gosline WA (1965) Vertical zonation of inshore fishes in the upper water layers of the Hawaiian Islands. Ecology 46: $823-831$

Harding GCH (1973) Decomposition of marine copepods. Limnol Oceanogr 18:670-673

Harman RF, Seki MP (1990) Iridoteuthis iris (Cephalopoda: Sepiolidae): new records from the central North Pacific and first description of the adults. Pacif Sci 44:171-179

Hobson ES (1972) Activity of Hawaiian reef fishes during the evening and morning transitions between daylight and darkness. Fish Bull US 70:715-740

Hobson ES (1991) Trophic relationships of fishes specialized to feed on zooplankters above coral reefs. In: Sales PF (ed) The ecology of fishes on coral reefs. Academic Press, San Diego, p 69-95

Hobson ES, Chess JR (1973) Feeding oriented movements of the atherinid fish Pranesus pinquis at Majuro Atoll, Marshall Islands. Fish Bull US 71:777-786

Lewis JB (1992) Heterotrophy in corals: zooplankton predation by the hydrocoral Millepora complanata. Mar Ecol Prog Ser 90:251-256

Nellen W (1973) Untersuchungen zur Verteilung von Fischlarven und Plankton im Gebiet der Großen Meteorbank. 'Meteor' Forsch-Ergebn 13:47-69

Ohman MD (1984) Omnivory by Euphausia pacifica: the role of copepod prey. Mar Ecol Prog Ser 19:125-131

Parin NV (1986) Distribution of mesobenthopelagic fishes in slope waters and around submarine rises. In: Pierrot-Bults AC, van der Spoel $S$, Zahuranec BJ, Johnson RK (eds) Pelagic biogeography. UNESCO tech Pap mar Sci 49: $226-229$

Parin NV, Prut'ko VG (1985) The thalassial mesobenthopelagic ichthyocoene above the Equator Seamount in the western tropical Indian Ocean. Oceanology 25: $781-783$

Perissinotto R, McQuaid CD (1992) Land-based predator impact on vertically migrating zooplankton and micronekton advected to a Southern Ocean archipelago. Mar Ecol Prog Ser 80:15-27

Ponomareva LA (1954) Copepods in the diet of euphausiids of the Sea of Japan. Dokl Akad Nauk SSSR 98:153-154

Redden AM, Daborn GR (1991) Viability of subitaneous copepod eggs following fish predation on egg-carrying calanoids. Mar Ecol Prog Ser 77:307-310

Reid SB, Hirota J, Young RE, Hallacher LE (1991) Mesopelagic-boundary community in Hawaii: micronekton at 
the interface between neritic and oceanic ecosystems. Mar Biol 109:427-440

Roe HSJ (1988) Midwater biomass profiles over the Madeira abyssal plain and the contribution of copepods. Hydrobiologia 167/168:169-181

Sameoto DD (1986) Influence of the biological and physical environment on the vertical distribution of mesozooplankton and micronekton in the eastern tropical Pacific. Mar Biol 93:263-279

Sebens KP, Koehl MAR (1984) Predation on zooplankton by the benthic anthozoans Alcyonium siderium (Alcyonacea) and Metridium senile (Actiniaria) in the New England subtidal. Mar Biol 81:255-271

Tate MW, Clelland RC (1957) Nonparametric and shortcut statistics. Interstate, Danville, IL

Terazaki M, Wada M (1988) Occurrence of large numbers of carcasses of the large, grazing copepod Calanus cristatus from the Japan Sea. Mar Biol 97:177-183

Weigmann R (1974) Untersuchungen zum Vorkommen der Euphausiaceen (Crustacea) im Bereich der Großen Meteorbank. 'Meteor' Forsch-Ergebn 17:17-32

Weikert $H$ (1975) Distribution and occurrence of pontellids (Copepoda, Calanoida) in the Central and South Atlantic Ocean. Meeresforsch 24:134-150

Weikert $H$ (1977) Copepod carcasses in the upwelling region south of Cap Blanc, N.W. Africa. Mar Biol 42:351-355

Weikert $H$ (1984) Zooplankton distribution and hydrography in the Mauritanian upwelling region off northwestern Africa, with special reterence to the calanoid copepods. Meeresforsch 30:155-171

Wheeler EH (1967) Copepod detritus in the deep sea. Limnol Oceanogr 12:697-701

This article was presented by J. E. Purcell (Senior Editorial Advisor), Cambridge, Maryland, USA
Wiebe PH, Copley N, Van Dover C, Tamse A, Manrique F (1988) Deep-water zooplankton of the Guaymas Basin hydrothermal vent field. Deep Sea Res 35:985-1013

Wiebe PH, Morton AW, Bradley AMI, Backus RH, Craddock JE, Barber V, Cowles TJ, Flierl GR (1985) New developments in the MOCNESS, an apparatus for sampling zooplankton and micronekton. Mar Biol 87:313-323

Wilson CD, Boehlert GW (1990) Acoustic measurement of micronekton distribution over Southeast Hancock Seamount, central Pacific Ocean. In: Singal SP (ed) Acoustic remote sensing. Proceedings of the Fifth International Symposium on Acoustic Remote Sensing of the Atmosphere and Oceans. McGraw-Hill Publications, New Delhi, p 222-229

Wilson CD, Boehlert GW (1993) Population biology of Gnathophausia longispina (Mysidacea: Lophogastrida) from a central North Pacific seamount. Mar Biol 115: $537-543$

Wilson CD, Firing E (1992) Sunrise swimmers bias acoustic Doppler current profiles. Deep Sea Res 39:885-892

Wishner KF (1980a) Aspects of the community ecology of deep-sea, benthopelagic plankton, with special attention to gymnopleid copepods. Mar Biol 60:179-187

Wishner KF (1980b) The biomass of deep-sea benthopelagic plankton. Deep Sea Res 27:203-216

Wishner $K$, Durbin $E$, Durbin A, Macaulay $M$, Winn $H$, Kenney R (1988) Copepod patches and right whales in the Great South Channel off New England. Bull mar Sci 43 : $825-844$

Yen J (1983) Effects of prey concentration, prey size, predator starvation and season on predation rates of the carnivorous marine copepod Euchaeta elongata. Mar Biol 75:69-77

Manuscript first received: July 14, 1994

Revised version accepted: January 31, 1995 